\title{
The Frankfurt School's Interest in Freud and the Impact of Eros and Civilization on the Student Protest Movement in Germany: A Brief History
}

\author{
Peter-Erwin Jansen \\ (Translated from the German by Charles Reitz)
}

In the following text, I will focus on three points that are connected to the impact of Herbert Marcuse's Eros and Civilization on the German student movement. First, I will show how Freud's theory was used in the late Twenties at the beginning of the Institute for Social Research in Frankfurt. Second, I will focus on how certain themes in the work of Adorno and Horkheimer are related to Marcuse's Eros and Civilization. Third, I will show how that work became relevant to the intellectual development of the student movement in Germany.

The significance of Freudian psychology and psychoanalysis for the project of Critical Theory as it was being developed early on by Max Horkheimer, Theodor W. Adorno, Erich Fromm, and Leo Löwenthal — the so-called inner circle of the Institute—has been emphasized in numerous historical studies published about the Frankfurt School (Jay; Wiggershaus; Kellner). Erich Fromm, in particular, was in large measure responsible for making Freudian theory relevant and fruitful for the development of a Critical Theory of society.

Marcuse, who was a vehement critic of Fromm during the 1950s, nonetheless acknowledged his key contributions to the Institute in a discussion with Jürgen Habermas: "Still the early works of Fromm, especially on the dogma of Christ, and the first essays in the Zeitschrift, they were incorporated as part of radical Marxist social psychology" (Habermas and 
Bovenschen 15). ${ }^{1}$ From 1930 to 1939 , Fromm was an official member of the Institute for Social Research. He left the Institute after a dispute with other members of the Frankfurt School during his exile in the United States.

Marcuse continued the discussion of Freud, and the debate with Erich Fromm, with his "Philosophical Inquiry into Freud," as Eros and Civilization is subtitled. In 1955 Marcuse justified a renewed examination of Freudian categories in the following manner:

Psychology could be elaborated and practiced as a special discipline as long as the psyche could sustain itself against the public power, as long as privacy was real, really desired, and self-shaped; if the individual has neither the ability nor the possibility to be for himself, the terms of psychology become the terms of the societal forces which define the psyche (xvii).

It was through the assistance of Löwenthal that not only Marcuse (on January $30^{\text {th }}$, 1933-the day of Hitler's takeover of power) became connected to the Institute for Social Research, but also (three years earlier) Fromm. Both Löwenthal and Fromm were born in 1900 in Frankfurt and belonged to a group of Jewish students that were strongly influenced by the charismatic Frankfurt Rabbi, Nehemiah Anton Nobel. ${ }^{2}$ A close friendship and a common interest in orthodox Jewish living resulted from this. These youthful friends began the study of psychology at Heidelberg University and they underwent analysis with Frieda Reichmann, a psychoanalyst born in 1889 in Königsberg, who directed a small psychoanalytic sanatorium. Therapy there was nicknamed "Tora-py" because it strictly conformed to Jewish rituals. The circle around Rabbi Nobel met at Reichmann's sanatorium and discussed texts by Martin Buber and Franz Rosenzweig. In 1926, at twelve years her junior, Fromm married Reichmann. Both were close friends of Löwenthal's first wife, Golde Ginsburg, who likewise came from Königsberg. 
In addition to these relationships, another contact was a significant precondition for the central position of psychoanalysis within the interdisciplinary research agenda of the Institute. In 1927, Horkheimer, who, like Adorno, had studied psychology in Frankfurt became, acquainted with the psychiatrist Karl Landauer, who was a disciple of Freud. Horkheimer himself underwent psychotherapy with Landauer. Marcuse, on the other hand, always declined to be analyzed. Even in old age, he continued to claim, ironically, that he had never needed it.

Scientific collaboration between the members of the Landauer group and the circle around Horkheimer began with the founding (on February $16^{\text {th }}, 1929$ ) of the Frankfurt Institute for Psychoanalysis. This organization, led by Landauer, had its first offices in the Frankfurt Institute for Social Research. On its staff were Fromm, Frieda Fromm-Reichmann, and Heinrich Meng. Landauer's newly opened Institute attracted even more attention when the City of Frankfurt's Goethe Prize was conferred upon the founder of psychoanalysis, Sigmund Freud, in 1930.

Horkheimer, who in the meantime had become the director of the Institute for Social Research, pointed explicitly to Fromm's central scientific research emphasis in his own publication from 1931, "Geschichte und Psychologie" ("History and Psychology"): "Erich Fromm is seeking to establish a social psychology upon a psychoanalytic foundation" $(61) .^{3}$ Horkheimer writes further that Freud's Massenpsychologie und Ich-Analyse (Mass Psychology and Ego-Analysis) is indispensable with regard to the larger set of issues surrounding "the relationship of the Führer and the masses" (Gesammelte Schriften, vol. 3 61). The significance of these statements is confirmed in Studien über Autorität und Familie (Studies on Authority and Family) that was published in Paris in 1936. Fromm was a key participant in these studies. "A theory of the family as an agency of society was formulated by Fromm on the basis of Freudian 
theory" according to Löwenthal in 1980 (73). Back in those earlier years Fromm was convinced that Freud's psychoanalytic approach was an indispensable elaboration of the agenda of Critical Theory. This interconnection is ably elucidated in Alfred Schmidt's preface to the third volume of the German language edition of Marcuse's unpublished papers, Philosophie und Psychoanalyse (Philosophy and Psychoanalysis):

Considering the later development of the relationship between Critical Theory and psychoanalysis, it nonetheless remains clear that Fromm's original notion of social psychology was intended to integrate classical type Freudian theory into historical materialism ("Einleitende Studie" 24).

In Schmidt's estimation, Fromm wanted to demonstrate through psychoanalysis that "ideologies ... are the products of particular wishes, drives, interests, and needs" (22).

The first contact between Marcuse and Fromm occurred while doing research for Studies on Authority and Family. Marcuse, who had assumed the leadership of the Institute's branch in Geneva in 1933, occasionally visited his professional colleague in Davos. Fromm resided in Davos (excluding a few brief interruptions) between 1931 and 1934 while being treated for tuberculosis of the lungs. The tentative beginnings of Marcuse's interest in psychoanalysis stem from these years. For example, without directly referring to Freud or to Fromm, Marcuse includes several reflections arising out of psychoanalytic theory in his essay "Towards a Critique of Hedonism" which was published in 1938 in the Zeitschrift für Sozialforschung. In these years he had not yet deepened his study of Freud. This would only change at the start of the Fifties, as Marcuse sought a new area of activity.

After his wartime service in the Office of Strategic Services, Marcuse held an official position in the State Department from 1945 until September $26^{\text {th }}, 1953$. Because of the coming of the Cold War, however, working conditions there deteriorated. By 1949, it was already clear to 
Marcuse that he should leave governmental service. But where should he go? To which other institution? Perhaps back to Frankfurt, where he might be able to work again with Horkheimer at the Institute, which was re-established in 1950? The period from 1950 through 1953 was a difficult time for Marcuse, both professionally and privately, until he secured a professorship at Brandeis University. Again and again his thoughts revolved around a return to Germany. Positive signals, for example, from Horkheimer about possibly succeeding Hans-Georg Gadamer, were followed by disappointment.

It is also doubtful that Marcuse was really very serious about wanting to return. Marcuse's first wife, Sophie Wertheim, was suffering from an incurable cancer. She died February $8^{\text {th }}, 1951$ in Washington. The loss of Sophie evoked a philosophical reconsideration and re-examination of death that went on for several years. The most visible outcome of these reconsiderations is the essay "The Ideology of Death" which was published in 1957 in the U.S.A. In a letter (dated March $3^{\text {rd }}, 1951$ ), circulated to his friends upon the death of his wife, he wrote: "The idea that death 'belongs to life' is false, and we should take Horkheimer's notion as much more serious and realizable: only with the abolition of death can humans really be free and happy. There is no more repugnant attitude than Heidegger's game-playing and transcendentalization of death. Teddie is perfectly correct: death is an absurdity and the only way to cope with it is to repress it. Nothing really helps."

Marcuse began to think anew about a return to the old continent. "Pollock has mentioned that you are thinking about doing something in Germany.... One could pursue most immediately a visiting professorship perhaps" (Horkheimer to Marcuse, April $3^{\text {rd }} 1951$, unpublished letter). At his request, the State Department gave Marcuse a leave of absence in 1950. He had an offer of a teaching position from the Washington School of Psychiatry, which he accepted, and taught 
there from 1950 to 1951. At that time Frieda Fromm-Reichmann, Fromm, and Ernst Schachtel (who Fromm knew well from his Heidelberg period and who also had contributed to Studies on Authority and Family) taught there. Marcuse's lecture course had the title, "Philosophical and Political Aspects of Psychoanalysis." One of the co-founders of the School of Psychiatry, which opened in 1936, was Harry Stack Sullivan. ${ }^{5}$ This psychiatrist from New York had already made it possible for Fromm to work at his institute during the late Thirties. It was at this time that Fromm undertook the revision of Freudian depth psychology that would lead to a decisive break with the Frankfurt School. The theoretical strife between Fromm, on the one hand, and Horkheimer and Adorno, on the other, left its traces also on the interpersonal level. Letters stopped being exchanged; contact ceased. A distant relationship developed even towards Löwenthal, the dear friend from their student days in Frankfurt and Heidelberg. Even Marcuse and Fromm, though they still occasionally exchanged letters, disagreed with each other publicly. All in all, though, the relationship remained chilled and tense.

Ultimately, the influence of Freud upon Marcuse's thought is most marked in the numerous texts that discuss the student movement and in his writings on the theory of emancipation. In "Aggressiveness in the Advanced Industrial Society," Marcuse writes:

(A)ggression activates destruction which 'aims' at death, while libido seeks the preservation, protection, and amelioration of life. Therefore, it is only as long as destruction works in the service of Eros that it serves civilization and the individual; if aggression becomes stronger than its erotic counterpart, the trend is reversed (257).

With a political interpretation of depth psychology, the philosopher of the student movement hoped to be able to emphasize its utopian potential for a theory of liberation.

In continuing accord with the original agenda of Critical Theory, Marcuse stressed, in a draft lecture (from November $1^{\text {st }}, 1974$ ) that he was not trying to replace Marx with Freud, but to 
make Marx more concrete through Freud. With Freud he wanted to investigate and understand ways to change the behaviour patterns of individuals, which Marx had neither analyzed under capitalism nor developed for socialism. However, in contrast to studies done during the 1930s, Marcuse makes clear:

The development of capitalism renders obsolete some key tenants of Freudian theory and practice, namely the conclusions of its (early) theory and therapy deriving from its consideration of early childhood experiences within the (bourgeois?) family. Today: the family is no longer the first agent of socialization determining the development of the individual. ... The family as agent of socialization, the father as representative of the reality principle, to a large extent have been replaced by the media, economic sanctions, peer groups, youth groups, sports teams, groups of all types. ${ }^{6}$

Furthermore, Marcuse also criticizes the recent academic fad that would become the search for identity. "The search for identity: as if identity only needed to be found like some kind of thing in order to be possessed! Searching is itself our identity; it is bounded only by our death" (draft lecture, November $\left.1^{\text {st }}, 1974\right)$.

Through Fromm, Freudian psychoanalysis became a significant component of the overall agenda of Critical Theory. Yet, as mentioned above, Horkheimer and especially Adorno let it be known that they were not interested in continuing to collaborate with Fromm. Later it fell to Marcuse, as to no other theoretician in the Frankfurt School's inner circle, to engage in an intellectual examination of Fromm's most recent position in the context of his own extraordinarily critical analysis of Freud. This occurred in Eros and Civilization in 1955, though the discussion of it in Germany did not take place until the 1960s. Marcuse recalled later that what had interested him at the Institute for Social Research at the beginning of the 1930s was the largely independent discussion of Marxist theory, the critical analysis of the political situation in Germany shortly before Hitler's rise to power, and psychoanalysis (Habermas and Bovenschen 
13). And he emphasizes here anew the important contributions of the early Fromm to the work of the Institute during the early 1930s.

\section{Horkheimer and Adorno as Influences}

Beginning in the 1960s, pirated editions of books published by members of the Institute for Social Research became available in German. Mostly these were essays and empirical studies from the 1930s and 1940s. Rediscovered were, for example, the investigations that comprised Studies in Prejudice. Special attention was given to an article written by Horkheimer, dedicated to the memory of Walter Benjamin in 1942, "The Authoritarian State." A distraught Benjamin had taken his own life on September $26^{\text {th }}, 1940$ in the Spanish border town of Portbou out of fear of falling into Nazi hands.

Beyond this, Adorno and Horkheimer's Dialectic of Enlightenment (1944) attained a belated renown during this period of the student movement. There, they had written that: "[C]ulture now impresses the same stamp on everything" (120). This is the fundamental insight of the book's chapter on the culture industry, which is occasionally mentioned today as an important influence upon student intellectuals in 1968. Yet a discussion of the real debates about the meaning of the book and its impact-and not only on the ' 68 student movement—is today deeply mired in forgetfulness. Forgotten is the political background and the historicalphilosophical nature of this work by Horkheimer and Adorno, even within Critical Theory itself.

This historical and theoretical background to Horkheimer and Adorno's book was formed by the accomplishments of the Enlightenment and its impetus towards emancipation. Kant's postulate that human beings could liberate themselves from their self-inflicted subordination (selbstverschuldeten Unmündigkeit) by virtue of their own mature intelligence, gave an 
optimistic quality to the Enlightenment. In view of the unspeakable crimes of the National Socialist dictatorship, however, the authors of the Dialectic of Enlightenment could no longer hold on to this optimistic vision. Because National Socialism had demonstrated how all human solidarity could be absolutely destroyed, they wanted to analyze: "[W]hy mankind, instead of entering into a truly human condition, is sinking into a new kind of barbarism" (Horkheimer and Adorno xi). The Dialectic of Enlightenment unflinchingly reconstructs the deterioration and destruction of reason in the history of philosophy and the process of the self-destruction of civilization. If reason may serve to preserve the individual and protect the autonomy of the human being, it has nonetheless under the capitalist system placed humanity in the service of, what they call, dominator power: the domination of human beings over nature and the domination of humans over humans.

The historical analysis presented by Horkheimer in the Eclipse of Reason, from 1947, written with the assistance of Löwenthal, probes even more deeply. It reflects on how the emancipatory impulses belonging to reason are converted into destructive ones. Progress threatens to destroy the goal it was originally supposed to attain: humanity. The idea of humanity, as it was naively and ideally imagined during the initial upsurge of the Enlightenment, has after Auschwitz forever lost its innocence. ${ }^{7}$

Along with the social analysis of the National Socialist system and its economic foundations, the intellectual exertions of the members of the Institute for Social Research were considered to revolve around the deconstruction of human subjectivity, down to its elementary ineffability (Unkennlichkeit). Horkheimer and Adorno sum-up in Dialectic of Enlightenment: "The lack of concern for the subject makes things easy for administration. Ethnic groups are 
forced to move to a different region; individuals are branded as Jews and sent to the gas chamber" (202).

The destruction of the European Jews, and the murder of millions of other human beings in the barbaric concentration camps of the Nazis, stood for (and stands for) the possibility of barbarism and the collapse of human civilization. Critical theorizing can thus not dispense with a critique of reason and civilization, nor can it rely on history merely to unfold in a progressive manner.

\section{Marcuse's Influence on the Students in 1968}

Certain elements of the activist students of ' 68 discovered the works of the early members of the Frankfurt School. The work of Horkheimer, Adorno, Fromm, Löwenthal and Marcuse, amongst others, was taken up in order to illumine the contours of contemporary social injustice, as well as to cast light upon the shadows of National Socialist mass murder lurking in the past. Adorno's "Reflections on a Damaged Life" (the subtitle to his Minima Moralia) is especially relevant here in coming to grips with the National Socialist barbarism. Those who understood the importance of Critical Theory of society for their own political activism were able to discover here important and also energizing philosophical impulses helpful in coping with contemporary crises.

Concerned scholars and scientists were united in their awareness that a more just world could only be made possible through the radical critique of the given forms of injustice. The suffering of the oppressed and the pain of the slaughtered demanded nothing less. Thus, solidarity with those who suffer and a radically oppositional form of thought were attainable, even if nothing else was, under conditions which members of the Frankfurt School felt had 
become rotten to the core. Löwenthal, for example, believed that Critical Theory was both an indictment of, and evidence against, an unjust world.

Marcuse's critique of the given suggests that a life of justice and of solidarity can be made real even when pre-conditioned by actually existing injustice. Nine years after the publication of Eros and Civilization, Marcuse's One-Dimensional Man came out. In this critical study of the "totally-administered society," many ideas appeared that have a connection to Eros and Civilization. I would now like to briefly turn to some of these. One-Dimensional Man is sometimes called the Bible of the student movement. In it, Marcuse's analysis of the present reflects ideas from the Dialectic of Enlightenment as well as from Horkheimer's Eclipse of Reason. He writes: "What begins as the horror of the concentration camps turns into the practice of training people for abnormal conditions" (One-Dimensional Man 80). The experiential basis for this bleak prognosis is not just the crimes of the Nazis. Marcuse is here speaking of advanced capitalist society, where, after 1945, the "peaceful production of the means of destruction" occurs, and which operates with highly sublimated mechanisms of repression (ix). The book was published at the same time as the protest movement was expanding. On multiple levels, those who read the book found grounds that legitimated their own resistance, even if not a single word can be found there about revolutionary political practice. The book is bleak and promises nothing. Its critique remains negative. Yet, in the end, its Critical Theory of society acknowledges the value of opposition and "wants to remain loyal to those who, without hope, have given and give their life to the Great Refusal" (257).

Such concepts as a "single-dimensional person" and a "totally-administered society" allowed the protesters to better focus on the political conditions of late industrial society with which they were confronted. New techniques of manipulation, like mass culture and the mass 
media, repressive forms for the gratification of needs, which confuse progress and personal consumerism, the expanding exploitation of developing nations, new technologies of domination and social control, demolish the regions of authentically individual experience and close-off the arenas of political activity. These forces threaten to integrate all authentic criticism and prevent all genuine opposition by reshaping them in a way that strengthens the actually existing system. To the contrary, Marcuse holds fast to his negative critique of the given form of society, which his analysis memorably described as "a comfortable, smooth, reasonable, democratic unfreedom" (One-Dimensional Man 1). Under the banner of technical progress, this society represses with new forms of control every alternative attempt at emancipation. But there are two sides to this coin: while the present organization of society powerfully blocks liberation, there are nonetheless historical alternatives. Emancipatory action can and must break entirely with the false continuum of progress.

Marcuse no longer assumes that the internal dynamics of capitalism will necessarily lead to a revolutionary overthrow of the powers that be. Just as today's capitalism has advanced through the accelerated productivity made possible through the heightened rationalization of the production process, so too has it been able to render the "objective factor obsolete. The new technological work-world thus enforces a weakening of the negative position of the working class: the latter no longer appears to be the living contradiction to the established society" (OneDimensional Man 51). In addition to this transformation of the infrastructure of the political economy, consumerism has fundamentally re-conditioned people's social lives and social consciousness. The efficient system of production, work, and progress gives rise to a happy consciousness through a repressive desublimation that penetrates into the psychological depths 
and drives of the individual. Marcuse, of course, devoted an entire volume, Eros and Civilization, to the working out of this position in 1955.

In contrast to Horkheimer and Adorno, Marcuse remained in the U.S.A., as did Löwenthal. It was not until 1956 that Marcuse was invited to return again to Germany for an official and important academic event. This was a conference organized in Heidelberg by Alexander Mitscherlich, the Director of the Sigmund Freud Institute, on the occasion of Freud's $100^{\text {th }}$ birthday. Marcuse was the only lecturer at the conference who was not a professional psychologist. He spoke about "Freedom and Freud's Theory of the Instincts" and about "Progress and Freud's Theory of the Instincts." 8 These two lectures, which were published in professional journals and had great impact, along with a new translation of Eros and Civilization, afforded Marcuse entrée into the realm of public academic discourse in Germany. In a 1968 interview in Der Spiegel, Mitscherlich declared: "It was through Herbert Marcuse that students of psychoanalysis learned that consciousness is not only conditioned by the material environment, but also by the dynamic of drives and their fate" (84).

For Marcuse's research, the point of departure here was: why is it that all revolutions hitherto have collapsed? For what reasons is history dominated by power and oppression? Why do people, at least partially, consent to, and submit to, the power of circumstance, even though options for liberation are available? Marcuse's development of the concepts "surplus-repression" (zusätzliche Unterdrückung) and "performance principle" (Leistungsprinzip) came to clarify the logic of domination (Herrschaft) and social control. Thus, Marcuse expanded Freud's psychoanalytic vocabulary and gave the analysis a socio-historical dimension. But what did Marcuse mean? Marcuse writes: 
Surplus-repression, the restrictions necessitated by social domination. This is distinguished from (basic) repression: the modifications of the instincts necessary for the perpetuation of the human race in civilization.

Performance principle: the prevailing historical from of the reality principle (Eros and Civilization 35).

Put very briefly, for Freud, the reality principle is anchored in the ego. The reality principle assists the ego in asserting itself and coping with the outside world; it performs the function of self-preservation. For Marcuse, the Freudian reality principle is interpreted in a politico-sociological sense within advanced capitalism. The reality principle is transplanted from the ego to the external world. According to his line of reasoning, it is grounded in alienated labour. Thus the historical form of the reality principle today is the performance principle, which requires surplus-repression and a one-dimensional rationality. "The irreconcilable conflict is not between work (reality principle) and Eros (pleasure principle), but between alienated labour (performance principle) and Eros" (Eros and Civilization 47n). But Eros and the pleasure-urge must be subordinated to the performance principle, which in a Freudian sense is meant to regulate the id. The pleasure urge "must learn to forget the claim for timeless and useless gratification, for the "eternity of pleasure" (47). But here "learning to forget" means sublimation and submission to the systemic requirements of capitalism for social control.

These brief remarks from Eros and Civilization highlight the key concepts that clarified to activists in the student movement their own sense of societal repression, the domination of capitalist social priorities, the authoritarian conduct of their parents' generation and their unspoken guilt for the crimes of national socialism, as well as their sexual prudery. Marcuse's reasoning was in line with the prevailing understanding within the student movement that 
psychoanalysis was a political philosophy and not a therapy of adjustment to the social status quo:

(W)hile psychoanalytic theory recognizes that the sickness of the individual is ultimately caused and sustained by the sickness of his civilization, psychoanalytic therapy aims at curing the individual so that he can continue to function as part of a sick civilization without surrendering to it altogether (245).

As Eros and Civilization unfolds, Marcuse attempts to demonstrate that a non-repressive maturation of our psychological drives is possible, one which will not, as Freud thought, inevitably result in the collapse of human culture: under the prevailing conditions, liberation appears as a destructive eruption; under alternate conditions of human life a "libidinal rationality" could emerge, which, in the form of a "new sensibility," could give rise to a qualitatively different kind of human interaction. In the anti-authoritarian student revolt, Marcuse saw that this new sensibility had become praxis. As he writes in An Essay on Liberation:

(I)t emerges in the struggle against violence and exploitation where this struggle is waged for essentially new ways and forms of life: negation of the entire Establishment, its morality, culture; affirmation of the right to build a society in which the abolition of poverty and toil terminates in a universe where the sensuous, the playful, the calm and the beautiful become forms of existence and thereby the Form of the society itself (25).

Marcuse's critical social theory and his critique of the prevailing forms of reason have probed deeply into the way in which the values, norms, and moral codes of the established system are rooted in the unconscious structure of our human impulses and drives. It would require a much more detailed analysis of the works of Marcuse than I can provide here in order to clarify his belief in the concrete possibility for emancipation and liberation. Yet, in conclusion, let me mention that, in an interview in 1977, Marcuse responds to a question about the political warrant for his hopefulness.

First of all, every day the real possibility of a reasonable human society increases. Secondly, the legacy of 1968, that is, of a radical revaluation of values that became 
visible at that time-radical ... in the sense that Freud formulated it, as a deeply searching effort to subordinate destructive energies to Eros (Habermas and Bovenschen 116).

Hope is pinned on fantasy and sensuousness as correctives to a merely instrumental form of reason, on our remembrance of the erotico-aesthetic dimension, and on the pleasure principle that seeks liberation and gratification.

Rudi Dutschke emphasized the political impact of Marcuse on the anti-authoritarian revolt, in a 1978 article in Neuen Forum, where he wrote that Herbert Marcuse's theoretical studies and his sense of history, as well as his demonstrative solidarity, helped to give a voice to those who would otherwise have been denounced as dreamers (58-65). Marcuse nonetheless always declined the distinction of being known as the philosopher of the student movement. He saw himself as having contributed to the Critical Theory of the capitalist and alienated society that had generated fascism, anti-Semitism, and oppression. The hopefulness for change, which he retained until the end of his life, was the outcome of his despair with regard to failed attempts at liberation. This is clear from his many ambivalent conclusions: for example, that this society is capable of preventing qualitative change for the foreseeable future. Yet forces still exist that can break through this paralysis and break open society. Marcuse even reminds us that "despair disappears at the same moment when we really do something against it. Certainly each of us in his own surroundings ... There is, or should be, no time for despair. Despair is something we do by ourselves" (Interview with Wiltraud Manfeld, "Questions to Herbert Marcuse about his Biography" 33-45). Perhaps now more than ever to be philosophical means to fight for a better society against the despair in ourselves. ${ }^{9}$ 


\section{Notes}

${ }^{1}$ See also Fromm's Die Entwicklung des Christusdogmas. Eine psychoanalytische Studie zur sozialpsychologischen Funktion der Religion; Über Methode und Aufgabe einer Analytischen Sozialpsychologie. Bemerkungen über Psychoanalyse und historischen Materialismus; and Die psychoanalytische Charakterologie und ihre Bedeutung für die Sozialpsychologie. All three are contained in his Gesamtausgabe.

${ }^{2}$ For a discussion, see Heuberger's "Die Entdeckung der jüdischen Wurzeln.”

${ }^{3}$ The text is contained in volume 3 of Horkheimer's collected works.

${ }^{4}$ The exchange of letters is contained in Max Horkheimer's collected works, vol. 18, 198-1999.

${ }^{5}$ Harry Stack Sullivan (1892-1949), whose main work, The Interpersonal Theory of Psychiatry, impressed Fromm, was also in contact with Karen Horney. Fromm published several important essays in Sullivan's Psychiatry. Journal for the Operational Statement of Interpersonal Relations. Marcuse included these three within the group he criticized as neo-Freudian revisionists. In July 1948, Sullivan and Horkheimer met at a UNESCO conference in Paris.

${ }^{6}$ Draft lecture of November 1, 1974, Marcuse-Archiv der Stadt und Universitätsbibliothek Frankfurt am Main.

7 Adorno formulates this view in Negative Dialectics, specifically in the chapter "After Auschwitz."

${ }^{8}$ Both lectures were republished in Five Lectures.

${ }^{9}$ The author wishes to thank Dalia Othman for her diligent work in type-setting the first edition of the article.

\section{Works Cited}

Adorno, Theodor W. Minima Moralia. London: Verso, 1984.

—. Negative Dialectics. New York: Continuum, 1997.

Dutschke, Rudi. "Pfad-Finder: Herbert Marcuse und die Neue Linke." Neues Forum, no. 297/298 (1978): 58-65.

Fromm, Erich. Gesamtausgabe. Vol. 1-12. Munich: Deutscher Taschenbuch. 1999. 
Habermas, Jürgen and Silvia Bovenschen, et. al. Gespräche mit Herbert Marcuse. Frankfurt am Main, 1978. 13, 15, 116.

Heuberger, Rachel. "Die Entdeckung der jüdischen Wurzeln" in Das Utopische soll Funken schlagen...Zum hundertsten Geburtstag von Leo Löwenthal. Edited by Peter-Erwin Jansen. Frankfurt am Main, 2000.

Horkheimer, Max. Eclipse of Reason. London: Continuum. 2004.

—. Gesammelte Schriften, Vol. 1-19. Frankfurt am Main: Fischer, 1943-1988.

Horkheimer, Max and Theodor W. Adorno. Dialectic of Enlightenment. New York: Herder and Herder, 1944.

Horkheimer, Max and Samuel H. Flowerman, editors. Studies in Prejudice. Vol.1-5. New York: Norton, 1949.

Jay, Martin. The Dialectical Imagination; A History of the Frankfurt School and the Institute of Social Research 1923-1950. Berkeley: University of California Press, 1973.

Kellner, Douglas. Erich Fromm. Biography (www.uta.edu/huma/illuminations/kell9).

Löwenthal, Leo. An Unmastered Past. The Autobiographical Reflections of Leo Loewenthal. Berkeley: University of California Press, 1987.

Marcuse, Herbert. "Aggressiveness in the Advanced Industrial Society" in Negations: Essays in Critical Theory. Boston: Beacon, 1968.

—. An Essay on Liberation. Boston: Beacon, 1969.

—. Eros and Civilization. A Philosophical Inquiry into Freud. Boston: Beacon, 1955.

—. Five Lectures. Boston: Beacon, 1970.

-. One-Dimensional Man. Studies in the Ideology of Advanced Industrial Society. Boston: Beacon, 1964.

—. Interview with Wiltraud Manfeld. "Questions to Herbert Marcuse about his Biography" in Befreiung denken - ein politischer Imperativ. Ein Materialienband zu Herbert Marcuse. Edited by Peter-Erwin Jansen. Offenbach, 1990. 33-45.

Mitscherlich, Alexander. "Vaterlose Gesellen.” Der Spiegel. No. 15 (April 8, 1968): 84. 
Schmidt, Alfred. "Einleitende Studie" in Philosophie und Psychoanalyse, Herbert Marcuse, Nachgelassene Schriften, Vol. 3. Edited by Peter-Erwin Jansen. Lüneburg, 2002. 15-95.

Wiggershaus, Rolf. The Frankfurt School. Its History, Theories, and Political Significance. London and Cambridge: Polity and The MIT Press, 1994. 